\title{
PERAN POLA KOMUNIKASI ANTARBUDAYA DALAM MENCEGAH KONFLIK ANTAR KELOMPOK AGAMA
}

\author{
Mochamad Rizak \\ Kementerian Agama Kota Semarang \\ Email : m.rizak@rocketmail.com
}

\begin{abstract}
$I$ ntercultural communication becomes a norm in the midst of society that has been globalized. There are no more regional boundaries and cultural barriers that travel between one person and another. But in reality, cultural differences often cause ripples of problems and even lead to the emergence of social conflict. This is due to the strengthening of ethnic identity that led to the emergence of ethnocentrism and stereotype in which one group feels superior to other ethnic groups

This study discusses the relationship of communication and culture that is like two sides of the coin. Culture shapes human thoughts and behavior and shapes our patterns of communication. While with communication we can convey the result of creation, desire and taste to others. This study wanted to examine matters relating to intercultural communication, especially on religious groups that led to the emergence of prejudice, causing a sense of mutual suspicion and even hostility between religious groups. In this case prejudice becomes an obstacle in communicating.

Intercultural communication aims to remove barriers as a result of cultural differences. As the principle of communication that the more like the cultural background will be more effective communication. Intercultural communication wants to make us human beings, ie people who look at others from the point of their culture not from the point of our culture so that will grow mutual respect.
\end{abstract}

Keywords: communication, culture, religious group

\section{ABSTRAK}

$\mathrm{K}$ omunikasi antar budaya menjadi norma di tengah-tengah masyarakat yang telah mengglobal. Tidak ada lagi batas-batas regional dan hambatan budaya yang bergerak antara satu orang dan yang lain. Namun dalam kenyataannya, perbedaan budaya sering menyebabkan riak masalah dan bahkan mengarah pada munculnya konflik sosial. Hal ini disebabkan menguatnya identitas etnis yang menyebabkan munculnya etnosentrisme dan stereotipe di mana satu kelompok merasa lebih superior dari kelompok etnis lain.

Studi ini membahas hubungan komunikasi dan budaya yang seperti dua sisi mata uang. Budaya membentuk pikiran dan perilaku manusia dan membentuk pola komunikasi kita. Sementara dengan komunikasi kita dapat menyampaikan hasil ciptaan, keinginan dan rasa kepada orang lain. Penelitian ini ingin meneliti hal-hal yang berkaitan dengan komunikasi antar budaya, terutama pada kelompok agama yang menyebabkan munculnya prasangka, menyebabkan rasa saling curiga dan bahkan permusuhan antar kelompok agama. Dalam hal ini prasangka menjadi kendala dalam berkomunikasi.

Komunikasi antarbudaya bertujuan untuk menghilangkan hambatan sebagai akibat dari perbedaan budaya. Sebagai prinsip komunikasi yang lebih menyukai latar belakang budaya akan komunikasi yang lebih efektif. Komunikasi antarbudaya ingin menjadikan kita manusia, yaitu orang yang melihat orang lain dari sudut budaya mereka bukan dari sudut budaya kita sehingga akan tumbuh saling menghargai.

Kata kunci: komunikasi, budaya, kelompok keagamaan 


\section{PENDAHULUAN}

Manusia adalah mahluk sosial. Ia dapat hidup, berkembang dan berperan ketika berhubungan dan bekerja sama dengan manusia lain. Salah satu cara agar dapat berhubungan dan bekerja sama adalah dengan komunikasi. Dengan komunikasi, seseorang dapat menyampaikan informasi, ide pemikiran, pengetahuan serta konsep kepada orang lain secara timbal balik Dengan komunikasi, manusia dapat diakui sebagai anggota masyarakat.

Komunikasi sendiri bukanlah sesuatu yang hampa. Komunikasi terjadi karena dikelilingi oleh banyak hal. Menurut Gudykunst dan Kim dalam Dedy Mulyana (2016:170) disebutkan, tentang empat hal yang mempengaruhi kita dalam berkomunikasi, yaitu : budaya, sosio budaya, psiko budaya dan lingkungan.

Budaya sangat berkaitan erat dengan komunikasi. Sebagaimana dikatakan Edward $\mathrm{T}$ Hall bahwa budaya adalah komunikasi dan komunikasi adalah budaya. Budaya sangat menentukan bagaimana cara kita berkomunikasi dengan orang lain, baik dengan orang yang berbudaya sama maupun dengan orang budayanya berbeda, Oleh karena itu, dengan pemahaman terhadap orang yang berbeda budaya maka komunikasi lebih efektif sehingga tujuan komunikasi dapat tercapai. (Suryani,2013:91-100) .

Konstruksi budaya yang diperoleh seseorang sejak kecil sangat mempengaruhi cara berpikir, berperilaku dalam berinteraksi dan berkomunikasi dengan orang yang berbeda budaya. Terjadinya benturan budaya (shock culture) adalah karena, kita yang cenderung menganggap budaya kita adalah benar dan memandang perilaku orang yang berbeda budaya dengan kita dengan pandangan subyektif .
Menurut Mulyana, dalam Nia Kurniati Syam dijelaskan bahwa untuk mencapai komunikasi yang efektif, khususnya dengan orang berbeda budaya yang harus kita lakukan adalah: (1) kita harus selalu menunda penilaian kita atas pandangan dan perilaku orang lain, karena penilaian kita tersebut seringkali bersifat subjektif, dalam pengertian berdasarkan persepsi kita sendiri yang tentunya sudah dipengaruhi oleh budaya kita atau dengan kata lain jangan biarkan stereotip menjebak dan menyesatkan kita ketika kita berkomunikasi dengan yang lain; (2) kita harus berempati dengan mitra komunikasi kita, berusaha menempatkan diri kita pada posisinya. Menggunakan sapaan sesuai dengan budayanya; (3) kita dituntut untuk selalu tertarik kepada orang lain sebagai individu yang unik, bukan sebagai anggota dari suatu kategori rasial, suku, agama atau sosial tertentu; (4) kita harus menguasai setidaknya bahasa verbal dan nonverbal dan sitem nilai yang mereka anut. (Nia Kurniati,2017:109-127)

Terkait dengan pemikiran Mulyana tersebut, menarik untuk melihat urgensitas pola komunikasi antarbudaya pada masyarakat kelompok agama. Hal ini karena pluraritas kelompok agama sudah menjadi karakteristik Bangsa Indonesia yang heterogen. Tidak dapat dipungkiri, pluralitas kelompok agama di negara ini memiliki potensi dan peran sangat besar dalam proses integrasi dan pembangunan. Namun pluralitas kelompok agama juga, bisa memicu terjadinya konflik dan disintegrasi bangsa, ketika melihat masingmasing kelompok agama memiliki klaim kebenaran absolut dan muatan emosi keagamaan yang menjadi dasar interaksi primer.

Terjadinya konflik Syiah-Sunni di Sampang Madura, Pengrusakan tempat 
ibadah Jamaah Ahmadiyah merupakan contoh bagaimana pluraritas kelompok agama menjadi masalah serius bagi kerukunan intern umat beragama di negara ini. Oleh karena itu, Komunikasi antarbudaya menjadi salah satu solusi bagi terciptanya kerukunan dan toleransi antar kelompok agama dalam menjalankan fungsi sosial mereka.

\section{PENGERTIAN KOMUNIKASI}

Komunikasi menurut Sukendar (2017:3)berasal dari bahasa Latin Communicatus atau communication atau communicare yang berarti berbagi atau menjadi milik bersama. Sehingga secara garis besar, dalam proses komunikasi harus ada unsur kesamaan makna agar terjadi pertukaran pikiran dan pengertian antara komunikator (penebar pesan) dan komunikan (penerima pesan).

Secara terminologis komunikasi memiliki banyak arti. Mulyana (2016:76) mengutip Donald Byker dan Loren J. Anderson mendefinisikan komunikasi adalah berbagi informasi antara dua orang atau lebih.

Hovland, Janis, \& Kelley, dalam Cangara (2014:14) mendefinisikan komunikasi sebagai sebuah proses dimana seorang individu (komunikator) mengirimkan stimulus untuk mengubah perilaku individu lainnya (audiens).

Sedangkan West \& Turner (2014:5) mengatakan bahwa komunikasi adalah proses sosial dimana individu menggunakan simbol untuk membentuk dan menafsirkan makna dalam lingkungan mereka.

Dari beberapa definisi di atas maka komunikasi merupakan sebuah proses sosial dimana terjadi perpindahan pesan dari pengirim ke penerima yang melibatkan proses penafsiran makna dengan tujuan tertentu.
Menurut Joseph Dominick dalam Morissan (2015:17) dijelaskan bahwa terjadinya komunikasi akan melibatkan delapan elemen komunikasi yang meliputi : sumber, encoding, pesan, saluran, decoding, penerima, umpan balik dan gangguan.

\section{JENIS KOMUNIKASI}

Berdasarkan jenisnya komunikasi dibagi menjadi dua, yaitu komunikasi verbal dan komunikasi nonverbal.

a. Komunikasi Verbal

$$
\text { Menurut Nurudin }
$$

Komunikasi verbal adalah bentuk komunikasi yang menggunakan kata-kata, baik lisan maupun tulisan. Komunikasi verbal adalah komunikasi yang banyak digunakan dalam hubungan antar manusia. Melalui kata-kata, kita dapat mengungkapkan perasaan, emosi, pemikiran, gagasan, atau maksud kita kepada orang lain. Dengan komunikasi verbal penyataan -pernyataan kita dapat diterima dan pesan kita tidak disalahtafsirkan orang lain. Dalam hal ini, bahasa memegang peranan penting terciptanyan komunikasi verbal. Menurut Hayakawa dalam Dedy Mulyana (2014:99), bahwa bahasa merupakan simbol yang paling rumit, halus dan berkembang. Bahasa menjadi sistem kesepakatan bersama untuk mewakili peristiwaperistiwa dalam kehidupan manusia.

Julia T. Wood, dalam Nurudin (2016:127132), mengemukakan bahwa ada tiga prinsip dalam komunikasi verbal, yakni :

Interpretasi menciptakan makna

Bahwa dalam sebuah pernyataan verbal akan banyak interpretasi yang muncul. Sebuah pesan yang disampaikan membawa konsekuensi makna yang dipahami. Hal ini karena setiap orang memiliki kemampuan berbeda dalam 
menangkap makna yang dipengaruhi berbagai faktor antara lain pengetahuan, latar belakang, kepentingan, tujuan komunikasi atau aspek psikologis seseorang.

1) Komunikasi adalah aturan yang dipandu

Komunikasi verbal dipandu aturanaturan tertentu. Bisa saja aturan tersebut adalah aturan yang tidak tertulis dan hanya kesepakatan bersama. Setiap komunitas mempunyai aturan tertentu yang tidak sama dengan komunitas lain. Aturan itu mencerminkan apa yang diucapkan, pilihan bahasa yang digunakan, konteks pesan yang disampaikan, dan lain sebagainya.

2) Penekanan mempengaruhi makna

Penekanan merupakan sebuah kesepakatan umum komunitas. Penekanan dalam komunikasi adalah untuk menciptakan makna. Ketika seseorang salah memahami makna penekanan maka akan terjadi kesalahan dalam interpretasi komunikasi.

\section{b. Komunikasi Nonverbal}

Komunikasi nonverbal menurut Suranto (2010:14) adalah komunikasi dengan ciri pesan yang disampaikan berupa pesan nonverbal atau bahasa isyarat, baik isyarat badaniah (gestural) maupun isyarat gambar (pictoral).Komunikasi nonverbal tidak menggunakan lambang verbal seperti kata-kata baik melalui percakapan maupun tulisan. Dalam kehidupan nyata komunikasi nonverbal lebih banyak dipakai daripada komunikasi verbal. Hal ini karena dalam setiap komunikasi, komunikasi nonverbal selau ikut terpakai. Itulah mengapa komunikasi nonverbal bersifat tetap dan selalu ada. Komunikasi nonverbal lebih jujur mengungkapkan hal yang mau diungkapkan karena spontan.

Komunikasi nonverbal dilakukan melalui kode-kode presentasional. Kode-

kode tersebut dapat memberikan pesan pada saat komunikasi terjadi. Kode-kode tersebut berfungsi memberikan informasi mengenai situasi pembicaan dan untuk mengatur hubungan antara pemberi pesan dengan penerima pesan. Argyle dalam Fiske (2012:110-115) mendata sepuluh kode presentasional dalam komunikasi nonverbal, yaitu :

1) Kontak tubuh

2) Kedekatan jarak

3) Orientasi

4) Penampilan

5) Anggukan kepala

6) Ekspresi wajah

7) Bahas tubuh,gesture

8) Postur

9) Gerakan mata atau kontak mata

10) Aspek nonverbal dari pembicaraan

Komunikasi nonverbal memiliki efektifitas dalam proses komunikasi dibanding komunikasi verbal. Dalam Siti Komsiah (TT:4), dijelaskan studi Albert Mahrabian (1971) yang menyimpulkan bahwa tingkat kepercayaan dari pembicaraan orang hanya $7 \%$ berasal dari bahasa verbal, 38\% dari vocal suara, dan $55 \%$ dari ekspresi muka. Ia juga menambahkan bahwa jika terjadi pertentangan antara apa yang diucapkan seseorang dengan perbuatannya, orang lain cenderung mempercayai hal-hal yang bersifat nonverbal.

Oleh karena itu, menurut De Vito (139140), penggunaan kode-kode nonverbal dalam komunikasi mempunyai fungsi :

1) Menekankan. Seperti mengeraskan suara atau memukul meja untuk menekankan apa yang diucapkan.

2) Melengkapi. Hal ini seperti tersenyum saat bercerita untuk memberi kesan humor. 
3) Menunjukkan kontradiksi seperti memuji orang tetapi sambil mencibirkan mulut.

4) Mengatur. Misalnya seseorang menempelkan jari telunjuk ke bibir yang berarti menyuruh orang lain diam.

5) Mengulang Misalnya menganggukkan kepala ketika mengatakan "ya" dan menggelengkan kepala ketika mengatakan "tidak".

6) Mengganti seperti mengatakan persetujuan dengan gestur tubuh.

Devito dalam Nurudin juga mengemukakan bahwa pesan-pesan nonverbal mempunyai ciri umum, yaitu :

a. Prilaku Komunikasi bersifat komunikatif, yaitu dalam situasi interaksi, perilaku demikian selalu mengkomunikasikan sesuatu.

b. Komunikasi nonverbal terjadi dalam suatu konteks yang membantu menentukan makna dari setiap perilaku nonverbal.

c. Pesan nonverbal biasanya berbentuk paket, pesan-pesan nonverbal saling memperkuat, adakalanya pesan-pesan ini saling bertentangan

d. Pesan nonverbal sangat dipercaya, umumnya bila pesan verbal saling bertentangan, kita mempercayai pesan non verbal.

e. Komunikasi nonverbal di kendalikan oleh aturan.

f. Komunikasi nonverbal seringkali bersifat metakomunikasi. Pesan nonverbal seringkali berfungsi untuk mengkomentari pesan-pesan lain baik verbal maupun nonverbal.

\section{BENTUK KOMUNIKASI}

a. Komunikasi Antar pribadi

Komunikasi Antarpribadi atau KAP sering disebut komunikasi interpersonal yaitu komunikasi antara dua orang atau lebih secara tatap muka. Sebagaimana yang dikatakan $\mathrm{R}$ Wayne, dalam Arianto
(2015:222), bahwa komunikasi antarpribadi adalah communication involving two or more people in a face to face setting. Dalam hal ini komunikasi antarpribadi terjadi secara tatap muka (face to face) yang memungkinkan pesertanya menangkap reaksi orang lain secara langsung.

Judy C. Pearson dalam Nia Kania menyebutkan komunikasi Antarpribadi sebagai komunikasi yang dimulai dengan diri pribadi (self). Maksudnya bahwa berbagai persepsi komunikasi yang menyangkut pemaknaan berpusat pada diri kita, yaitu dipengaruhi oleh pengalaman dan pengamatan kita.

Fungsi komunikasi antarpribadi atau komunikasi interpersonal menurut Cangara (2004:63) adalah berusaha meningkatkan hubungan insani (human relations), menghindari dan mengatasi konflik-konflik pribadi, mengurangi ketidak pastian sesuatu, serta berbagi pengetahuan dan pengalaman orang lain.

Komunikasi antarpribadi sangat penting untuk mencapai tujuan komunikasi karena sifatnya yang dialogis. Dalam dialog terjadi interaksi antara komunikator dan komunikan yang masing-masing berfungsi ganda yaitu sebagai pembicara dan pendengar secara bergantian. Ada upaya dari para pelaku komunikasi untuk terjadinya pengertian bersama (mutual understanding) dan empati.

Effendy dalam Mukti Sitompul mengatakan bahwa komunikasi antarpribadi dinilai paling ampuh dalam kegiatan mengubah sikap, kepercayaan, opini dan prilaku komunikan dibandingkan dengan bentuk-bentuk komunikasi yang lain. Hal ini disebabkan komunikasi antarpribadi umumnya berlangsung secara tatap muka (face-to-face communication). Dengan komunikasi tatap muka, terjadi 
kontak pribadi (personal contact), dimana pribadi komunikator menyentuh pribadi komunikan. Ketika komunikator menyampaikan pesan, ketika itu pula terjadi umpan balik langsung (immediate feedback).

Dengan demikian,komunikator dapat mengetahui apa tanggapan komunikan terhadap pesan yang disampaikannya. Apabila pesan yang disampaikan itu dapat menyenangkan komunikan (umpan balik positif), maka komunikator dapat mempertahankan gaya komunikasinya, tetapi apabila tanggapan komunikan itu negatif, maka komunikator harus mengubah gaya komunikasinya.

Dengan demikian dapat dikatakan bahwa komunikasi antarpribadi adalah salah satu bentuk komunikasi yang efektif dalam merubah pendapat, sikap, kepercayaan, opini dan perilaku. Komunikasi persuasif sebagai salah satu tehnik komunikasi antarpribadi sering digunakan untuk melancarkan ajakan, bujukan yang dapat membangkitkan kesadaran individu.

Keberhasilan suatu kegiatan komunikasi didasarkan kepada berbagai faktor. Para pakar telah mengemukakan agar proses komunikasi itu bisa berhasil maka harus mengetahui karakteristik komunikasi itu sendiri. Dalam komunikasi antarpribadi menurut Joseph A.Devito dalam Dasrun Hidayat (2012:43), ada lima karakteristik komunikasi antarpribadi yang efektif, yaitu keterbukaan, empati, dukungan, perasaan positif dan kesamaan.

Dalam menunjukkan kualitas keterbukaan (openness) dari komunikasi antarpribadi, dapat dilihat dari tiga aspek, yaitu: 1) keinginan untuk terbuka bagi setiap orang yang berinteraksi dengan orang lain, 2) keinginan untuk menanggapi secara jujur stimuli yang datang padanya, dan 3) mengenai perasaan dan pikiran kita, artinya mengakui perasaan dan pikiran yang kita ungkapkan dan kita pertanggungjawabkan.

Selanjutnya, empati (empathy) artinya merasakan sebagai mana yang dirasakan oleh orang menjadi perasaan bersama.

Karakteristik komunikasi antarpribadi selanjutnya adalah dukungan (supportiveness) Dengan adanya dukungan akan tercapai komunikasi antar pribadi yang efektif. Dukungan adakalanya terucapkan dan adakalanya tidak terucapkan.

Karakteristik yang keempat adalah kepositifan (positiveness). Komunikasi antarpribadi akan berhasil jika seseorang mempunyai sikap positif terhadap dirinya dalam menyampaikan perasaan kepada orang lain. Komunikasi antarpribadi juga akan terpelihara baik jika suatu perasaan positif terhadap orang lain itu dikomunikasikan.

Yang terakhir adalah kesamaan (equality). Suasana komunikasi antarpribadi akan lebih efektif apabila ada kesamaan, seperti kesamaan pendidikan, budaya, status dan lain sebagainya.

a. Komunikasi Kelompok

Yaitu interaksi tatap muka dari tiga atau lebih individu guna memperoleh maksud dan tujuan tertentu yang dikehendaki seperti berbagi informasi, pemeliharaan diri atau pemecahan masalah sehingga semua anggota dapat menumbuhkan karakteristik pribadi anggota lainnya dengan akurat.(Daryanto,2014:88) Komunikasi kelompok dapat dipetakan menjadi 3 kelompok komunikasi yaitu;

1) Small groups (kelompok yang berjumlah sedikit); yaitu komunikasi yang melibatkan sejumlah orang dalam interaksi satu dengan yang lain dalam suatu 
pertemuan yang bersifat berhadapan. Ciriciri kelompok seperti ini adalah kelompok komunikan dalam situasi berlangsungnya komunikasi mempunyai kesempatan untuk memberikan tanggapan, dalam hal ini komunikator dapat berinteraksi atau melakukan komunikasi antar pribadi.

2) Medium groups (agak banyak); Komunikasi dalam kelompok sedang lebih mudah sebab bisa diorganisir dengan baik dan terarah, misalnya komunikasi antara satu bidang dengan bidang yang lain dalam organisasi atau perusahaan.

3) Large groups (jumlah banyak); merupakan komunikasi yang melibatkan interaksi antara kelompok dengan individu, individu dengan kelompok, kelompok dengan kelompok. Komunikasinya lebih sulit dibandingkan dengan dua kelompok di atas karena tanggapan yang diberikan komunikan lebih bersifat emosional.

\section{b. Komunikasi Massa}

Menurut (Romli, 2016:1) komunikasi massa yaitu pesan yang dikomunikasikan melalui media massa pada sejumlah besar orang. Karakteristik media massa antara lain:

1) Pesan-pesan yang disampaikan terbuka untuk umum.

2) Komunikasi bersifat heterogen, baik latar belakang pendidikan, asal daerah, agama yang berbeda, kepentingan yang berbeda.

3) Media massa menimbulkan keserempakan kontak dengan sejumlah besar anggota masyarakat dalam jarak yang jauh dari komunikator.

4) Hubungan komunikator-komunikan bersifat interpersonal dan non pribadi.

\section{POLA KOMUNIKASI}

Pola komunikasi adalah rangkaian dua kata, yaitu pola dan komunikasi. Keduanya memiliki keterkaitan makna sehingga antara satu sama lain saling mendukung.
Dalam Kamus Besar Bahasa Indonesia kata "pola" dapat diartikan dengan sistem ; cara kerja, bentuk (struktur) yang tetap. Pola juga diartikan dengan bentuk atau cetakan.

Pola sebagai model merupakan gambaran yang abstrak dan sistematis, yaitu cara untuk menunjukkan sebuah objek yang mengandung kompleksitas proses di dalamnya dan hubungan antara unsur-unsur pendukungnya. Menurut Little John dalam Wiryanto (2004:9), model dapat diterapkan pada setiap representasi simbolik dari suatu benda.

Pola komunikasi diartikan sebagai bentuk atau pola hubungan dua orang atau lebih dalam proses pengiriman dan penerimaan cara yang tepat, sehingga pesan yang dimaksud dapat dipahami. Menurut Soenarto dalam Firdaus dikatakan bahwa dimensi pola komunikasi terdiri dari dua macam, yaitu pola yang berorientasi pada konsep dan pola yang berorientasi pada sosial yang mempunyai arah hubungan yang berlainan.

Tubbs dan Moss (2005:27) mengatakan bahwa pola komunikasi atau hubungan antara dua orang atau lebih itu dibagi menjadi tiga :

a) Bersifat komplementer. Hubungan komplementer didasarkan pada perbedaan diantara orang yang terlibat. Satu bentuk perilaku akan diikuti oleh lawannya. Contohnya perilaku dominan dari satu partisipan mendatangkan perilaku tunduk pada lainnya.

b) Bersifat simetri, tingkatan sejauh mana orang berinteraksi atas dasar kesamaan. Dominasi bertemu dengan dominasi, atau kepatuhan dengan kepatuhan.

c) Bersifat sejajar yaitu pola hubungan yang merupakan kombinasi dari komplementer dan simetris. 
Disini kita mulai melihat bagaimana proses interaksi menciptakan struktur sistem. Bagaimana orang merespon satu sama lain menentukan jenis hubungan yang mereka miliki.

Pola komunikasi merupakan gambaran yang sederhana dari proses komunikasi yang memperlihatkan kaitan antara satu komponen komunikasi dengan komponen lainnya. Pola Komunikasi diartikan sebagai bentuk atau pola hubungan dua orang atau lebih dalam proses pengiriman, dan penerimaan cara yang tepat sehingga pesan yang dimaksud dapat dipahami.

Dengan demikian maka suatu pola komunikasi merupakan gambaran atau rencana yang meliputi langkah-langkah pada suatu aktifitas, dengan komponenkomponen yang merupakan bagian penting atas terjadinya hubungan komunikasi antar manusia atau kelompok dan organisasi. Pola komunikasi adalah bentuk atau pola hubungan antara dua orang atau lebih dalam proses mengkaitkan dua komponen yaitu gambaran atau rencana yang menjadi langkah-langkah pada suatu aktifitas dengan komponen-komponen yang merupakan bagian penting atas terjadinya hubungan antar organisasi ataupun juga manusia.

\section{KOMUNIKASI ANTARBUDAYA}

Komunikasi antarbudaya (KAB) adalah komunikasi yang terjadi diantara orang-orang yang memiliki kebudayaan yang berbeda (bisa ras, etnis, atau sosioekonomi, atau gabungan dari semua perbedaan ini). Sebagaimana Alo Liliweri (2009:12-13) mengatakan KAB sebagai interaksi dan komunikasi antarpribadi yang dilakukan oleh beberapa orang yang memilki latar belakang kebudayaan yang berbeda. Komunikasi antarbudaya terjadi bila produsen pesan adalah anggota suatu budaya dan penerima pesannya adalah anggota suatu budaya lainnya.

Komunikasi dan kebudayaan merupakan dua hal yang tidak dapat dipisahkan sebagaimana ET. Hall menyebut budaya adalah komunikasi dan komunikasi adalah budaya. Kebudayaan membentuk pikiran dan tingkah laku manusia dan melalui komunikasi kita menyampaikan pola perubahan budaya.

Komunikasi yang efektif ditandai oleh makna yang diterima komunikan sama dengan makna yang disampaikan komunikator. Semakin mirip latar belakang sosial-budayanya maka semakin efektif komunikasi yang terjadi . Bahasa, gesture, dan pakaian / aksesoris yang digunakan oleh seseorang bisa menjadi refleksi dari budaya yang dimiliki orang tersebut. Disisi lain, adanya komunikasi yang baik antar satu generasi dengan generasi lainnya akan mempermudah melestarikan budaya suatu kelompok.

Dalam hal ini, budaya dalam komunikasi antarbudaya tidak hanya terbatas pada adat-istiadat, tari-tarian ataupun hasil kesenian lainnya. Budaya dalam komunikasi antarbudaya adalah yang mewujud pada aspek material kebudayaan atau kebudayaan dalam bentuk bendabenda kongkret dan aspek non-materia yaitu kebudayaan dalam bentuk kaidahkaidah dan nilai-nilai kemasyarakatan untuk mengatur hubungan yang lebih luas termasuk agama, ideologi, kesenian dan semua unsur yang merupakan ekspresi jiwa manusia. (Liliweri, 2014:12-14)

Untuk memahami terjadinya komunikasi antarbudaya ada tiga dimensi yang perlu diperhatikan, antar lain :

a) Tingkat masyarakat kelompok budaya dari partisipan, seperti :

- Kawasan di dunia, misalnya budaya timur, budaya barat; 
- Nasional/Negara

- Kelompok-kelompok etnis-ras dalam negeri

- Subkelompok sosiologis

b) Kontek sosial tempat terjadinya komunikasi antarbudaya.

c) Saluran yang dilalui oleh pesan-pesan komunikasi antarbudaya ( verbal atau nonverbal) (Soyomukti,2016:331)

\section{UNSUR-UNSUR KAB}

Alo Liliweri

(2013:25-31)

menyebutkan unsur unsur proses komunikasi antarbudaya meliputi :

a) Komunikator

Komunikator dalam komunikasi antarbudaya adalah pihak yang mengawali pengiriman pesan tertentu kepada pihak lain yang disebut komunikan. Dalam komunikasi antarbudaya, seorang komunikator berasal dari latarbelakang kebudayaan tertentu yang berbeda dengan komunikan yang berkebudayaan B.

b) Komunikan

Komunikan adalah pihak yang menerima pesan. Dalam memahami pesan sangat tergantung dari tiga bentuk pemahaman, yakni : (1) kognitif, komunikan menerima isi pesan sebagai sesuatu yang benar; (2) afektif, komunikan percaya bahwa pesan itu tidak hanya benar tetapi baik dan disukai; dan (3) overt action atau tindakan nyata, di mana seorang komunikan percaya atas pesan yang benar dan baik sehingga mendorong tindakan yang tepat.

Pesan / simbol

Pesan adalah pikiran, ide, atau gagasan,perasaan yang dikirim komunikator kepada komunikan dalam bentuk simbol. Simbol adalah sesuatu yang digunakan untuk mewakili maksud tertentu baik verbal atau nonverbal. Setiap pesan mengandung aspek utama : content dan treatment, yaitu isi dan perlakuan. Isi pesan meliputi aspek daya tarik pesan, misalnya kontroversi, keaktualan (baru), argumentatif, rasional atau emosional. Sedangkan perlakuan atas pesan berkaitan dengan penjelasan atau penataan isi pesan oleh komunikator. Pilihan isi dan perlakuan atas pesan tergantung dari ketrampilan komunikasi, sikap, tingkat pengetahuan, posisi dalam sistem sosial dan kebudayaan.

\section{Media}

Media merupakan tempat, saluran yang dilalui oleh pesan atau simbol yang dikirim melalui media tertulis atau media massa. Tetapi terkadang pesan-pesan itu dikirim tidak melalui media, terutama dalam komunikasi antarbudaya tatap muka. Para ilmuwan sosial menyepakati dua tipe saluran; (1) sensory channel atau saluran sensoris, yakni saluran yang memindahkan pesan sehingga akan ditangkap oleh lima indra, yaitu mata, telinga, tangan, hidung dan lidah. (2) institutionalized means, atau saluran yang sudah sangat dikenal dan digunakan manusia, misalnya percakapan tatap muka dan media massa. Setiap saluran institusional memerlukan dukungan satu atau lebih saluran sensoris untuk memperlancar pertukaran pesan dari komunikator kepada komunikan.

\section{Efek / umpan balik}

Umpan balik merupakan tanggapan balik dari komunikan kepada komunikator atas pesan-pesan yang telah disampaikan. Tanpa umpan balik atas pesan-pesan dalam komunikasi antarbudaya maka komunikator dan komunikan tidak bisa memahami ide, pikiran dan perasaan yang terkandung dalam pesan tersebut.

\section{Suasana}

Suasana adalah tempat (ruang, space) dan waktu (time) serta suasana (sosial, psikologis) ketika komunikasi antarbudaya 
berlangsung. Suasana itu berkaitan dengan waktu (jangka pendek/panjang, jam/hari /minggu/bulan/tahun) yang tepat untuk bertemu/berkomunikasi, sedangkan tempat (rumah, kantor, rumah ibadah) untuk berkomunikasi, kualitas relasi (formalitas, informalitas) yang berpengaruh terhadap komunikasi antarbudaya.

Gangguan

Gangguan dalam komunikasi antarbudaya adalah segala sesuatu yang menjadi penghambat laju pesan yang ditukar antar komunikator dengan komunikan, atau mengurangi makna pesan antarbudaya . ada tiga macam gangguan ; (1) fisik, berupa interfensi dengan transmisi fisik isyarat atau pesan lain, (2) psikologisinterfensi kognitif atau mental, misalnya prasangka dan bias pada sumber-penerimapikiran yang sempit; dan (3) semantikberupa pembicara dan pendengar memberi arti yang berlainan.

\section{PRINSIP-PRINSIP KAB}

Prinsip-Prinsip Komunikasi

Antarbudaya dapat dibagi menjadi 6 bagian yaitu:

a) Relativitas Bahasa

Gagasan umum bahwa bahasa mempengaruhi pemikiran dan perilaku paling banyak disuarakan oleh para antropologis linguistik. Pada akhir tahun 1920-an dan disepanjang tahun 1930-an, dirumuskan bahwa karakteristik bahasa mempengaruhi proses kognitif kita. Dan karena bahasa-bahasa di dunia sangat berbeda-beda dalam hal karakteristik semantik dan strukturnya, tampaknya masuk akal untuk mengatakan bahwa orang yang menggunakan bahasa yang berbeda juga akan berbeda dalam cara mereka memandang dan berpikir tentang dunia

b) Bahasa Sebagai Cermin Budaya

Bahasa mencerminkan budaya.Makin besar perbedaan budaya, makin besar perbedaan komunikasi baik dalam bahasa maupun dalam isyarat-isyarat nonverbal. Makin besar perbedaan antara budaya (dan, karenanya, makin besar perbedaan komunikasi), makin sulit komunikasi dilakukan.Kesulitan ini dapat mengakibatkan, misalnya, lebih banyak kesalahan komunikasi, lebih banyak kesalahan kalimat, lebih besar kemungkinan salah paham, makin banyak salah persepsi, dan makin banyak potong kompas (bypassing).

c) Mengurangi Ketidak-pastian

Makin besar perbedaan antarbudaya, makin besarlah ketidak-pastian dan ambiguitas dalam komunikasi. Banyak dari komunikasi kita berusaha mengurangi ketidak-pastian ini sehingga kita dapat lebih baik menguraikan, memprediksi, dan menjelaskan perilaku orang lain. Karena letidak-pasrtian dan ambiguitas yang lebih besar ini, diperlukan lebih banyak waktu dan upaya untuk mengurangi ketidakpastian dan untuk berkomunikasi secara lebih bermakna.

d) Kesadaran Diri dan Perbedaan

Antarbudaya

Makin besar perbedaan antarbudaya, makin besar kesadaran diri (mindfulness) para partisipan selama komunikasi.Ini mempunyai konsekuensi positif dan negatif. Positifnya, kesadaran diri ini barangkali membuat kita lebih waspada.ini mencegah kita mengatakan hal-hal yang mungkin terasa tidak peka atau tidak patut. Negatifnya, ini membuat kita terlalu berhati-hati, tidak spontan, dan kurang percaya diri.

e) Interaksi Awal dan Perbedaan

Antarbudaya

Perbedaan antarbudaya terutama penting dalam interaksi awal dan secara berangsur berkurang tingkat kepentingannya ketika hubungan menjadi 
lebih akrab. Walaupun kita selalu menghadapi kemungkinan salah persepsi dan salah menilai orang lain, kemungkinan ini khususnya besar dalam situasi antarbudaya.

f) Memaksimalkan Hasil Interaksi

Dalam komunikasi antarbudaya seperti dalam semua komunikasi kita berusaha memaksimalkan hasil interaksi. Tiga konsekuensi yang dibahas oleh Sunnafrank (1989) mengisyaratkan implikasi yang penting bagi komunikasi antarbudaya. Sebagai contoh, orang akan berintraksi dengan orang lain yang mereka perkirakan akan memberikan hasil positif. Karena komunikasi antarbudaya itu sulit, anda mungkin menghindarinya. Dengan demikian, misalnya anda akan memilih berbicara dengan rekan sekelas yang banyak kemiripannya dengan anda ketimbang orang yang sangat berbeda. (De Vito:479-488)

\section{HAMBATAN KAB}

Hambatan dalam komunikasi antarbudaya bersumber dari tiga faktor , yaitu faktor psikologis, ekologis dan faktor mekanis. Faktor psikologis berkaitan dengan kondisi kejiwaan seseorang yang mempengaruhi baik secara positif maupun negative terhadap jalannya komunikasi. Faktor ekologis berkaitan dengan kekuatankekutan eksternal yang mempengarhi peserta komunikasi, seperti perbedaan sosial ekonomi atau kondisi lingkungan seperti riuh, bising, hujan, petir dan faktor alam lain yang mempengaruhi terjadinya komunikasi. Sedangkan faktor mekanis berkaitan dengan media atau tehnologi yang digunakan dalam berkomunikasi, seperti pertemuan, festival, telekonferensi, chat, dsb. (Shoelhi,2015:17-18)

Disamping ketiga hambatan tersebut, hambatan yang berupa perbedaan budaya sangat besar dalam mempengaruhi terjadinya komunikasi antara komunikator dan komunikan. Menurut Purwasito, hambatan yang bersumber pada perbedaan kebudayaan lebih menonjol pada faktor heterofili sehingga komunikasi tidak berjalan lancar. Tujuan komunikasi akan lebih lancar apabila partisipan komunikasi mempunyai persamaan (homofili).

Hambatan-hambatan dalam komunikasi yang berkaitan dengan faktor budaya dapat dikategorikan sebagai berikut :

a) Perbedaan norma sosial

Norma sosial merupakan suatu cara, kebiasaan, tata karma, adat istiadat, dan kepercayaan yang dianut secara turun temurun yang dapat memberikan petunjuk bagi seseorang untuk bersikap dan bertingkah laku dalam pergaulan masyarakat .

Keragaman etnik menyebabkan terjadinya keragaman norma sosial yang tidak menutup kemungkinan terjadinya pertentangan nilai. Kebiasaan dan adatistiadat yang dianggap baik suatu masyarakat belum tentu dianggap baik pula oleh masyarakat lain. Agar tidak terjadi hambatan maka komunikator perlu mengkaji apakah pesan yang akan disampaikan tidak melanggar norma tertentu.

b) Etnosentrisme

Etnosentrisme adalah penilaian terhadap kebudayaan lain atas dasar nilai dan standar budaya sendiri. Dalam etnosentrisme sebuah komunitas menganggap budaya superior dibanding budaya lain. Peserta komunikasi yang berbeda budaya dapat menggagalkan komunikasi.

c) Stereotip dan prasangka

Stereotip adalah konsepsi mengenai sifat suatu golongan masyarakat berdasarkan prasangka yang subjektif dan tidak tepat. Stereotip mampu menghambat 
komunikasi antarbudaya. Orang yang bersikap strereotip cenderung menempatkan orang di luar kelompoknya sebagai out group.

d) Perbedaan perspektif

Perspektif adalah cara pandang suatu objek, benda atau peristiwa berdasarkan pengamatan seseorang. Cara pandang seseorang sangat ditentukan oleh budaya yang dianutnya. Persepsi yang sama akan memudahkan dan melancarkan komunikasi.

\section{e) Perbedaan pola pikir}

Pola pikir berkaitan dengan pencarian kebenaran yang mengandalkan rasionalitas. Pola pikir seseorang atau kelompok orang berbeda satu sama lain sebagai akibat pengalaman dan acuan yang digunakan. Pola pikir sangat berpengaruh terhadap reaksi, rangsangan, dan tanggapan individu dalam berkomunikasi dengan individu yang berasal dari budaya lain.

\section{f) Faktor Bahasa}

Bahasa sebagai alat komunikasi sering menjadi hambatan utama dalam komunikasi ketika para peserta komunikasi tidak memiliki persamaan bahasa.

g) Faktor sintaksis dan semantik

Hambatan semantik dapat terjadi dalam beberapa bentuk. Pertama, adanya pengertian konotatif atau denotatif. Kedua, adanya perbedaan makna dan pengertian untuk kata atau istilah yang sama sebagai akibat aspek psikologis. Ketiga, Komunikator salah mengucapkan kata-kata karena tergesa-gesa.

h) Ketidakmerataan Pendidikan

Kesenjangan pendidika antara masingmasing masyrakat sering meyebabkan terjadinya kegagalan komunikasi.

i) Gegar budaya
Gegar budaya adalah disorientasi psikologis yang dialami seseorang ketika seseorang bergerak dalam periode tertentu ke dalam sebuah lingkungan budaya yang berbeda dari budaya mereka sendiri. Berada di tengah lingkungan yang berbeda budaya menyebabkan seseorang salah tingkah sehingga menyebabkan komunikasi tidak efektif dan terhambat. (Shoelhi,2015:1725)

\section{KELOMPOK AGAMA DAN PRASANGKA SOSIAL}

Hidup berkelompok merupakan sifat bawaan manusia. Dengan berkelompok akan terjadi tukar menukar informasi dan pengalaman yang akan saling mempengaruhi diantara anggotanya.

Kelompok agama merupakan salah satu kelompok sosial. Sebagaimana dikatakan Sherif dalam Asnafiyah (2008:116) bahwa kelompok sosial adalah kesatuan sosial yang terdiri atas dua atau lebih individu yang telah mengadakan interaksi sosial dan terdapat pembagian tugas, struktur dan norma-norma tertentu yang khas bagi kesatuan sosial tersebut.

Sebagai kelompok sosial, kelompok agama oleh Cooley dikelompokkan sebagai kelompok primer (primary group). Dimana terdapat interaksi sosial yang lebih intensi dan lebih erat antara anggotanya dan masing-masing diikat oleh hubungan batin yang murni dan bersifat alamiah serta bersifat kekal. Dasar hubungan tersebut adalah rasa cinta dan rasa persatuan batin yang bersifat nyata dan organis.

Sebagai kelompok sosial, kelompok agama memiliki budaya yang berkembang yang berbeda dengan kelompok lainnya. Agama dalam hal ini, tidak dilihat sebagai identitas global, tetapi dipandang sebagai kebenaran kelompok. Agama sebagai sebuah keyakinan yang berisi nilai kebenaran yang universal dalam prakteknya 
hanya dilihat melalui sudut pandang masing-masing kelompok tertentu. Islam tidak dilihat sebagai sebuah identitas tetapi merupakan sesuatu yang menghadirkan begitu banyak makna implementasi, seperti Islam syiah, sunni, kejawen, sunda wiwitan, dan sebagainya. (Dedi Kurnia Syah,2016:15)

Kelompok agama terbentuk karena masing-masing anggotanya memiliki citacita yang didasarkan pada nilai atau norma yang sama terhadap sesuatu yang bersifat sakral. Hal ini akan menumbuhkan in group feeling yang cenderung ekslusif terhadap out group feeling. (Alo LIliweri,2011:255) Adanya ikatan antar anggota yang bersifat emosional, kepercayaan yang kuat serta komitmen terhadap kelompoknya serta bersama-sama melakukan norma dan nilai yang diyakini tersebut pada akhirnya akan melahirkan identitas kelompok. Dalam perkembangannya kemudian kelompokkelompok tersebut berkembang menjadi aliran / sekte agama.

Isajiw (1999) dalam Rajab Ali dkk (2010:20), menjelaskan bahwa identitas kelompok agama meliputi dua aspek yaitu: Aspek internal yang merujuk pada citra (images), ide (ideas), sikap (attitudes), dan perasaan (feeling) yang kemudian dibagi dalam empat dimensi yaitu affective (afektif), Fiducial (kepercayaan), cognitive (kognitif), moral (moral). Aspek eksternal ditunjukkan oleh perilaku yang dapat diamati (observable behaviours) yang meliputi: logat (dialek) bahasa; praktek tradisi ; keikutsertaan dalam jaringan kerja kelompok agama tersebut seperti keluarga dan persahabatan; dan terlibat dalam institusi.

Akibat yang ditimbulkan dari identitas kelompok agama adalah munculnya etnosentrisme. Etnosentrisme adalah paham dimana penganut suatu kebudayaan atau suatu kelompok merasa lebih superior dibanding kelompok diluar mereka. Dalam komunikasi antarbudaya etnosentrisme meningkatkan kecenderungan untuk memilih dengan siapa kita berkomunikasi. Menurut Zastrow dalam Alo Liliweri (2011:170), etnosentrisme akan menyebabkan timbulnya prasangka sebagai upaya untuk mempertahankan ciri kelompok secara berlebihan. Semakin kuat identitas dan etnosentrisme suatu kelompok terhadap kelompok lain maka semakin kuat pula prasangka sosial yang timbul.

Allport dalam Alo Liliweri (2009:199201) mengatakan bahwa prasangka adalah antipati berdasarkan generalisasi yang salah atau generalisasi yang tidak luwes. Antipati tersebut dapat dinyatakan atau dirasakan. Antipati itu bisa ditujukan pada kelompok atau individu kelompok tertentu. Pada mulanya prasangka merupakan pernyataan didasarkan pengalaman dan keputusan yang tidak teruji namun saat ini pernyataan prasangka lebih diarahkan pada pandangan emosional dan negatif terhadap seseorang atau sekelompok orang dibandingkan dengan kelompok sendiri.

Gundykunst mengatakan bahwa prasangka bersumber dari timbulnya kesadaran terhadap sasaran prasangka (kelompok lain) yaitu kesadaran bahwa (1) mereka adalah kelompok lain yang berbeda latar belakang kebudayaan serta mental (kesadaran "kami" versus "mereka"); (2) kelompok lain tidak mampu beradaptasi; (3) kelompok lain selalu terlibat dalam tindakan negatif (penganiayaan, kriminalitas); dan (4) kehadiran kelompok lain dapat mengancam stabilitas sosial dan ekonomi. Selanjutnya, Johnson mengemukakan bahwa prasangka disebabkan oleh stereotipe dan perasaan 
superior kelompok dan yang menjadikan kelompok lain inferior.

Prasangka negatif terhadap kelompok atau seseorang terdiri tiga tipe :

1) Prasangka kognitif, yaitu cara berpikir "benar atau salah" menurut kelompok tertentu terhadap orang atau kelompok lain.

2) Prasangka afektif, yaitu perasaan berbeda "suka atau tidak suka" terhadap orang atau kelompok lain.

3) Prasangka konatif, yaitu sikap diskriminatif atau agresif terhadap suatu kelompok. (Sholehi,2015:49-50)

Menurut Johnson (1986) dalam Sihabudin dan Amirudin (2008:205), bahwa prasangka yang didasari rasisme, (agama) dan etnisitas , erat dengan keberhasilan komunikasi sesama manusia. Prasangka merupakan salah satu rintangan atau hambatan bagi suatu kegiatan komunikasi. Orang yang memiliki prasangka akan bersikap curiga terhadap komunikator. Ia akan mudah menarik kesimpulan berdasarkan emosi tanpa menggunakan logika dan realita yang sebenarnya. Dengan prasangka sebuah komunikasi akan terhambat karena salah satu pihak menganggap negatif terhadap kelompok atau seseorang yang berada di luar kelompoknya.

\section{KOMUNIKASI ANTARBUDAYA DALAM MENCEGAH KONFLIK ANTAR KELOMPOK AGAMA}

Komunikasi adalah sebuah proses dinamis yang berlangsung secara terusmenerus. Dalam komunikasi terjadi proses pengiriman pesan atau simbol-simbol yang mengandung arti dari seorang sumber atau komunikator kepada seorang penerima atau komunikan dengan tujuan tertentu.

Komunikasi dikatakan efekti apabila tujuan komunikasi tercapai , apabila masing-masing pelaku yang terlibat didalam proses komunikasi mempunyai persepsi yang sama terhadap simbol. Namum, apabila terjadi perbedaan persepsi maka dapat dikatakan bahwa tujuan komunikasi gagal.

Salah satu prinsip komunikasi adalah semakin mirip latar belakang budaya maka semakin efektilah komunikasi. Sebagaimana dikatakan E.T. Hall, budaya adalah komunikasi dan komunikasi adalah budaya. Komunikasi antarbudaya dilakukan untuk mencari kesepahaman dan saling pengertian antara orang-orang yang memiliki latar belakang kebudayaan yang berbeda. Perbedaan budaya orang yang berkomunikasi ini menyangkut kepercayaan, nilai, serta berperilaku kultur di lingkungan mereka.

Perbedaan budaya harus dipahami sebagai sebuah kewajaran dalam interaksi sosial. Menurut Anugrah dan Kresnowati dalam Aminullah (2015:273) dikatakan bahwa perbedaan budaya tidak menjadi halangan untuk satu sama lain menjalin hubungan (relationship), yang terpenting adalah saling memahami (understanding), saling beradaptasi (adaptation) dan saling bertoleransi (tolerance). Kunci utama dari pergaulan antarbudaya adalah tidak menilai orang lain yang berbeda budaya dengan menggunakan penilaian budaya sendiri. Biarkan semua berjalan dengan latar budaya masing- masing. Justru perbedaan budaya adalah ladang untuk siapapun belajar budaya orang lain dengan arif dan bijak (wise). Tanpa adanya pemahaman perbedaan budaya maka akan menyebabkan terjadinya kesalahpahaman, ketegangan antar satu budaya dengan budaya yang lain termasuk didalamnya ketegangan kelompok agama sebagaimana yeng terjadi di negara kita. 
Schramm dalam Mulyana dan Rahmat (2014:6-7) menyatakan bahwa komunikasi antarbudaya yang efektif harus memperhatikan empat syarat, yaitu : 1) menghormati anggota budaya lain sebagai manusia; 2) menghormati budaya lain sebagaimana apa adanya bukan sebagaimana yang kita kehendaki; 3) menghormati hak anggota budaya yang lain untuk bentindak berbeda dari cara kita bertindak; 4) komunikator lintas budaya yang kompeten harus belajar menyenangi hidup bersama orang dari budaya lain.

Terjadinya konflik suku, agama, ras dan antar golongan disebabkan adanya sikap stereotip dan etnosentrisme karena menguatnya identitas kelompok. Stereotip dan etnosentrisme akan menjadi penghambat efektifitas komunikasi karena meletakkan individu-individu dalam kelompok sendiri, kemudian memandang kelompok sendiri berbeda dengan kelompok lain. Perbedaan ini menyebabkan timbulnya jarak antara kelompok satu dengan yang lain karena sikap superior terhadap kelompok lain diluar kelompoknya dan akan melahirkan jarak sosial.

Lustig \& Koester dalam Liliweri (2009:238) mengatakan bahwa strategi dalam upaya mengurangi konflik suku, agama, ras dan antar golongan sebagai akibat menguatnya identitas kelompok adalah memahami hakikat komunikasi budaya. Memahami bahwa komunikasi antarbudaya adalah komunikasi yang simbolik, interpretatif, transaksional, dan berproses dalam sebuah konteks dengan derajat perbedaan antarmanusia yang demikian luas dan penting, yang mencakup tidak suku, agama, ras dan antar golongan melainkan kebudayaan dalam menginterpretasi simbol antarbudaya.
Snare dalam Liliweri (2009:37-38) mengatakan, konflik dan komunikasi antarbudaya dapat diselesaikan melalui dialog yang baik, antara lain dengan identifikasi budaya. Hanya dengan komunikasi berbagai macam konflik dapat diselesaikan. Disini, konflik dipandang sebagai unsur alamiah dari komunikasi yang mengalami hambatan, konflik hadir sebagai katalisator untuk memperbesar pengertian dan kerjasama antarmanusia.

Konflik sebagai akibat stereotip dan etnosentrisme dalam komunikasi antarbudaya dapat dikurangi dalam beberapa tahapan :
a. Mengurangi cara berpikir etnosentrisme.
b. Berempati dalam komunikasi sebagaimana apa adanya bukan sebagaimana yang kita kehendaki.
c. Relativisme budaya yaitu menempatkan semua kebudayaan secara setara.
d. Mencari dan menciptakan media antarbudaya untuk menyatukan simbol antarbudaya.

Soyomukti

(2016:348-350) mengatakan bahwa konflik etnis, agama dan ideologi sebagai akibat benturan budaya dapat direduksi ketika manusia mempunyai etika global. Etika global adalah patokan budi realitas dan sebabsebab objektif dan imbasnya bagi disharmonisasi sosial, budaya, agama dan etnisitas yang rawan terjadi. Etika global tidak saja mencari titik temu antara kekayaan lokalitas dan mendukung keragaman budaya, tetapi juga mencari titik temu untuk mengatasi ketidakadilan global.

Untuk memwujudkan etika global maka harus ada pergeseran nilai dalam paradigma kehidupan manusia yang menurut Hans Kung dalam Soyomukti adalah : 
a) Perubahan dari masyarakat bebas etis kepada masyarakat bertanggung jawab secara etis.

b) Dari budaya teknokrasi menuju teknologi yang melayani manusia.

c) Dari industri yang merusak lingkungan menuju industri yang ramah lingkungan.

d) Dari demokrasi legal menuju demokrasi yang berkeadilan dan berkebebasan.

Komunikasi antarbudaya merupakan proses komunikasi sosial yang salah satu tujuannya adalah untuk mengurangi tingkat ketidakpastian terhadap orang lain. Menurut Lary Mary dalam Andi Eka Putra (2017:2), bahwa dalam konteks relasi antarkelompok agama, proses komunikasi sosial meniscayakan adanya saling keterbukaan sehingga terbangun sikap saling kesepahaman sebagai lawan sikap etnosetrisme yang menunjukkan sikap tak peduli dengan yang lain yang mengakibatkan timbulnya kebencian dan permusuhan.

Komunikasi sosial merupakan sarana membangun kohesi atau ikatan kebersamaan dalam suatu komunitas. Melalui komunikasi sosial, berbagai kesenjangan dapat dinegosiasikan, didiskusikan dan dicarikan pemecahan masalahnya secara beradab. Proses komunikasi sosial menuntut adanya saling pengertian dua belah pihak sehingga proses komunikasi berjalan dengan lancar dan baik.

\section{KESIMPULAN}

Hubungan antar kelompok agama sering menjadi masalah serius bagi kerukunan umat manusia. Hal ini karena etnosentrisme dan stereotip sebagai akibat menguatnya identitas kelompok menyebabkan suatu kelompok menganggap diri mereka superior dibanding kelompok lainnya. Sikap lebih baik itu pada akhirnya akan menimbulkan prasangka dan konflik konflik di masyarakat.

Salah satu strategi untuk mengatasi konflik antar kelompok, dalam hal ini kelompok agama adalah melalui komunikasi antarbudaya. Tujuan dari komunikasi antarbudaya adalah mengurangi ketidakpastian diantara pelaku komunikasi yang berbeda kebudayaan. Pelaku komunikasi dituntut untuk menjadi manusia berbudaya yaitu manusia yang memahami budaya orang lain sehingga akan timbul keterbukaan dan saling menghormati satu sama lain.

\section{DAFTAR PUSTAKA}

\section{BUKU :}

Canggara, H. Hafied, 2004. Pengantar Ilmu Komunikasi, Jakarta :PT. Raja Grafindo Persada

Daryanto, 2014, Teori Komunikasi, Malang : Gunung Samudera

Hidayat, Dasrun, 2012, Komunikasi Antarpribadi dan Medianya, Yogyakarta : Graha Ilmu 2012.

Devito, Joseph A., The Interpersonal Communication Book, www.pearsonhighered.com,

Fiske, John 2012, Pengantar Ilmu Komunikasi, Jakarta : Rajawali Pers.

Liliweri, Alo, 2009, Prasangka dan Konflik, Yogyakarta : LkiS,

Liliweri, Alo, 2009, Makna Budaya Dalam Komunikasi Antarbudaya, Yogyakarta : Lkis

\section{1, Gatra-Gatra}

Komunikasi Antarbudaya, Yogyakarta : Pustaka Pelajar.

Komunikasi

2013, Dasar-Dasar Yogyakarta : Pustaka Pelajar. 
Peran Pola Komunikasi Antarbudaya...Hal 88-104

2014, Pengantar Studi

Kebudayaan, Bandung : Nusa Media. . 2015, Teori-Teori Komunikasi Antarbudaya, Yogyakarta:Pelangi Aksara.

Morissan, 2015, Teori Komunikasi, Jakarta : Prenadamedia Group

Mulyana, Dedy, 2014 Jalaludin Rahmat, Komunikasi Antarbudaya, Panduan Berkomunikasi dengan Orang-Orang Berbeda Budaya, Bandung : PT. Remaja Rosda Karya,

Mulyana, Dedy, 2016, Ilmu Komunikasi Suatu Pengantar, Bandung : Rosdakarya.

Nurudin. 2016, Ilmu Komunikasi Ilmiah dan Populer, Jakarta: Rajawali Pers.

Romli, Khomsahrial , 2016, Komunikasi Massa, Jakarta : Kompas Media

Suranto Aw, 2010, Komunikasi Sosial Budaya, Yogyakarta ; Graha Ilmu.

Syah, Dedi Kurnia, 2016, Komunikasi Lintas Budaya, Bandung : Simbiosa Rekatama Media.

Shoelhi, Mohammad, 2015, Komunikasi Lintas Budaya, Bandung · Simbiosa Rekatama Media.

Sukendar, Markus Utomo, 2017, Psikologi Komunikasi, Yogyakarta : Deeppublish.

Soyomukti, Nurani , 2016, Pengantar Ilmu komunikasi, Jogjakarta : Ar-Ruzz Media.

Tubbs, Stewart L. dan Slyvia Moss, 2005, Human Communication Bandung : Remaja Rosdakarya.

Wiryanto, 2004, Pengantar Ilmu Komunikasi, Jakarta : Grasindo, 9

West, Richard, Lynn Hill Turner, Introducing Communication Theory McGraw-Hill Education, 2014.
JURNAL :

Arianto, "Menuju Persahabatan" Melalui Komunikasi Antarpribadi Mahasiswa Beda Etnis"Kritis Jurnal Sosial Ilmu Politik, Universitas Hasanudin, Vol. 1,(2015): 222

Asnafiyah, "Kelompok Keagamaan dan Perubahan Sosial", Jurnal Aplikasi Ilmu-Ilmu Agama, Vol. IX, (2008) : 116

Aminullah dkk, Model Komunikasi Antarbudaya Etnik Madura dan Etnik Melayu, Jurnal Komunikasi Aspikom, 2 ( 2015): 273

Andi Eka Putra, Membangun Komunikasi Sosial, Jurnal Al Adyan, 12(2017): 2

Ahmad Sihabudin dan Suwaib Amirudin,

Prasangka Sosial dan Efektifitas Komunikasi Antarkelompok, Jurnal Mediator, 9 (2008): 205

Mukti Sitompul, Pengaruh Efektifitas Komunikasi Antarpribadi Panti Asuhan terhadap Pembentukan Konsep Diri Anak-Anak Panti Asuhan Aljamyatul Wasilah Medan, Jurnal Simbolika, 1 ( 2015) : 177

Rajab Ali, dkk, Hubungan antara Identitas Etnik dengan Prasangka terhadap Etnik Tolaki pada Mahasiswa Muna di UniversitasHaluoleo Kendari Sulawesi Tenggara, Jurnal Psikologi Undip 7 (2010) : 20

Syamsurizal, Strategi Komunikasi Persuasif Dalam Aktivitas Pemasaran, Jurnal Lentera Bisnis, 5 ( 2016) : 127

Syam, Nia Kurniati, et al. "Adaptation in Different Religious Marriage." PROSIDING 1.1 (2017): 109-127. 